\title{
The Strategies of Transnational Advocacy Networks: A Support to Anti-Fracking Movement In The United Kingdom (2013-2019)
}

\section{Amelinda Fairuz Azura \& Silvia Dian Anggraeni}

\author{
Amelinda Fairuz Azura \\ Affiliation : Universitas Pertamina \\ City : Jakarta \\ Country : Indonesia \\ Email \\ amelindafairuzazura@gmail.com
}

\section{Silvia Dian Anggraeni}

$\begin{array}{lll}\text { Affiliation } & : & \text { Universitas Pertamina } \\ \text { City } & : & \text { Jakarta } \\ \text { Country } & : & \text { Indonesia } \\ \text { Email } & \vdots & \\ \text { silvia.da@universitaspertamina.ac.id }\end{array}$

\section{History}

$\begin{array}{lcc}\text { Submission } & : & \text { 12 March } 2021 \\ \text { Review } & : & \text { 17 May } 2021 \\ \text { Completed } & & \\ \text { Accepted } & : & \text { 1 June } 2021 \\ \text { Available } & : & \text { 5 June } 2021 \\ \text { Online } & & \end{array}$

DOI :

10.51413/jisea.Vol2.Iss1.2021.54-74

\section{Copyright}

This is an open access article distributed under the term of the creative commons attribution 4.0 international licence

\begin{abstract}
The implementation of fracking activities in United Kingdom that involves the pumping of water, chemicals, and sand underground to explore shale gas has caused several hazardous impacts. This situation has sparked protests from various kinds of demonstrators, both individuals and organizations. In response to the public objection to fracking activities, the British Government tended to fight back against the action. The detention of demonstrators ultimately created a pattern of limited advocacy among the public against the British Government. It has prompted an NGO called Friends of the Earth to start mobilizing these issues to the international realm by promoting principled ideas or norms to form a transnational network, aiming to influence national policy. The authors explain the transnational advocacy network's role in influencing British policy by applying the concept of Transnational Advocacy Network (TAN) from Margaret E. Keck and Kathryn Sikkink. Specifically, the role is analysed based on TAN's strategies, namely Information Politics, Symbolic Politics, Leverage Politics, and Accountability Politics. The authors also use Constructivism Theory to explain how norms and ideas can influence national policy. This research uses qualitative methods with secondary data collection techniques to describe and interpret some relevant phenomena to become an integrated explanation.
\end{abstract}

Key Words: Anti-Fracking, NGOs, International Advocacy Network, United Kingdom

\section{Cite this article :}

Azura, A. F., \& Anggraeni, S. D. (2021). The Strategies of Transnational Advocacy Networks: A Support to AntiFracking Movement In The United Kingdom (2013-2019). Journal of International Studies on Energy Affairs, 2(1), 54-74. https://doi.org/10.51413/jisea.Vol2.Iss1.2021.54-74 


\section{INTRODUCTION}

Fracking or hydraulic fracturing is a stimulation technique used by shale gas producers, involving the pumping of water, chemicals and sand underground (CPRE, 2018). Fracking is to crack the rock walls in the well that have been excavated and extracting shale gas from the rock layers with high pressure of chemical fluid so that the shale gas can flow through the cracks. The British Government began to actively encourage the exploration of unconventional oil and gas industry when Prime Minister David Cameron announced that the Government would act optimally to implement fracking to boost the economy and increase new jobs. It is known that England's geographical location contains oil in the south and gas in the north. Therefore, the UK uses fracking stimulation techniques to maximize shale gas production. In May 2011, the first exploration of shale oil and gas began using the fracking technique at Preese Hall, Lancashire. This fracking activity eventually triggered two small earthquakes and created seismic instability (British Geological Society, 2018).

Along with these problems, certain communities have started to raise concerns about the direct impact on the local natural environment, including soil, air and water pollution, and the broader problem of maintaining dependence on fossil fuels in the face of the global climate. The first major protests against fracking in England and Wales took place in the summer of 2013 at Balcombe in Sussex, where a coalition of local groups and environmental activists set up a protest camp on an exploration drilling site run by an energy company, Cuadrilla. Some of these protests have been ongoing for months, with continuous action by protesters seeking to highlight opposition to shale gas extraction. However, there are limitations to advocacy between local communities and British rule. This can be seen through several examples of the British Government's resistance to the actions being carried out, such as the detention of more than 200 demonstrators in a demonstration procession using violent means (Perraudin \& Pidd, 2018).

The resistance to influence policy changes related to fracking is increasingly being carried out, involving local actors and several NGOs that have brought this problem across national borders. These various NGOs have connections with other NGOs outside British territory boundaries, linked by viral information. It has triggered international responses from multiple parties, including the European Union, which showed a commitment to the anti-fracking movement in 2014, which was appointed in the Green Council Copenhagen Spring by the European Greens Party. In this regard, the European Union shows its full commitment and puts pressure on member countries to minimize fracking action and its impacts (European Parliamentary Research Service, 2014). Moreover, anti-fracking support also comes 
from the United Nations which issued an anti-fracking warning through the Committee on the Elimination of Discrimination against Women (CEDAW) to completely ban fracking on March 14, 2019 (Hayhurst, 2019).

The role of the international advocacy networks related to fracking practice in the UK, met its expectation in 2019 when the British Government issued a moratorium which technically means a temporary ban on the implementation of fracking (Peters, 2019). Research on the role of international advocacy networks in supporting the UK's anti-fracking movement in 2013 - 2019 can also illustrate that disseminating values and ideas can be an influential factor in adjusting certain policies. Therefore, it is interesting to examine international advocacy networks' role in supporting the UK's anti-fracking movement in 2013 - 2019.

\section{Literature Review and Statement of Art}

To maintain originality, the researchers try to describe several relevant literature studies. The following are some of the previous studies that were used as references in this study. The first reference used is a journal article written by Joanna Gillmore in 2019, entitled "Protesters' experiences of policing at anti-fracking protests in England, 2016-2019: a national study" (Gillmore, 2019). This journal article discusses various kinds of actions against fracking activities in the UK. In addition, this journal article also discusses the British Government's actions and police who often conflict with protesters voicing their views on fracking activities. Protesters have reported experiences of violence, intimidation and aggression from police officers.

The second literature reference comes from a journal article entitled "Shale we drill? Discourse dynamics in UK fracking debates", written by Elizabeth Bomberg in 2017 (Bomberg, 2017). This journal explains the differences in political discourse around the fracking method in England, by involving two parties arguing with each other, namely those who are pro to fracking activity (shale opportunity) and those who oppose it (shale threat). The third reference is two journal articles from Citra Hennida (2015) entitled "The Spiral and Boomerang Model On Transadvocacy Networks Case: The Sarayaku Ecuador" and from Young Sokphea (2016) entitled "Transnational Advocacy Networks in International Supply Chains: A Study of Civil Society Organizations: Sugar Movements in Cambodia". These two journal articles discuss the use of the Boomerang Pattern in Transnational Advocacy Networks in solving domestic problems, which are then brought to the international realm to influence policy in a domestic issue.

Margaret Keck and Kathryn Sikkink's works (1999) also reflect a constructivism trait. They explain that NGOs operating within a country can mobilize various 
issues or norms through interactions with NGOs or international organizations outside the country's territory. In analyzing the British public advocacy network's role against the anti-fracking movement amid the blocking of advocacy access to the Government, the authors use the concept of Transnational Advocacy Networks (TAN) proposed by Margaret E. Keck and Kathryn Sikkink. TAN is a network consisting of international actors working on an issue, bound together by shared values and discourses, as well as information exchanges. The transnational network seeks to promote ideas and norms based on specific issues, usually soft power. These issues, which are generally domestic, have become a concern among the international community, thus forming a transnational network that aims to advocate for policy change on an issue of their concerns and interests (Keck \& Sikkink, 1999). There are four strategies that the transnational advocacy networks maintain to achieve their goals and targets, namely:

\section{Information Politics}

In this strategy, TAN uses many information exchange techniques, such as telephone calls, e-mail communications, and faxes, providing credible education and knowledge to the public about certain issues that may not have been available before, such as the distribution of newsletters and pamphlets. These methods can greatly impact changing state behavior in formulating a policy to deal with certain issues.

\section{Symbolic Politics}

Transnational networks frame certain problems with symbolic politics or giving a strong impression through symbols, actions, or stories that describe the situation or demands of activists. The implication is to get many people to change their minds and take collective action to address a particular issue.

\section{Leverage Politics}

Leverage politics involves actors who are considered vital in a country's government system to participate in a series of transnational advocacy networks. Politically, it can have a direct impact on the policies of the Government of that country. This is because these actors who are considered strong will make it easier for a transnational network to gain influence and public attention so that they are able to influence state policy directly.

4. Accountability Politics 
Accountability politics is an effort to evaluate existing networks on the advocacy results. In this context, activists try to test government accountability through implementing policies on a particular issue with an agreed commitment.

\section{METHOD}

Through the Transnational Advocacy Networks approach, the authors focus on the TAN actors' four strategies to push for the moratorium. Furthermore, in answering research questions, the authors use Qualitative Research Methods. Qualitative research is a useful approach to explore, understand, or interpret phenomena in the context of meaning brought by the subject or object involved in the phenomenon (Creswell, 2013). Using qualitative method, the authors describe and interpret the role of international advocacy networks in supporting the anti-fracking movement amid barriers to advocacy access to the British Government in 2013 - 2019. In this study, the unit of explanation is the involvement of international advocacy networks in the UK; While the unit of analysis is the goal of the UK's anti-fracking movement from 2013 to 2019. The timeframe of 2013-2019 shows various efforts of the advocacy networks conducted by NGOs and environmental activists against fracking activities amid the barriers of access to the UK Government until the enactment of moratorium or temporary ban of those activities.

The authors apply secondary data collection techniques, mostly internet-based, to support argumentation and built integrated explanations (Bakry, 2016). Some of the main keywords used in the literature search were "Fracking in England", "Antifracking Protests in England", "Anti-fracking Movements", and "Fracking Effects on Environment". The literature obtained based on these main keywords is in journals, books, papers, dissertations, or research reports. These sources are compiled in the bibliography.

The research phases began by collecting data on the background of fracking activities that triggered opposition from the British community, the parties involved in international advocacy, and the objectives and development of the results of the international advocacy network on fracking activities in the UK. After obtaining valid and credible data, researchers analyze the role of international advocacy networks in supporting the anti-fracking movement amid the blocking of advocacy access to the British Government. The data are then linked to the existing conceptual framework so that the role of the advocacy network against the antifracking movement can be concluded as an effective explanation. 


\section{RESULT AND DISCUSSION}

\section{The Beginnings of the Fracking Method and Its Impacts in United Kingdom}

Britain is one of the countries that consumes natural gas on a large scale. In 2018, gas consumption met nearly two-thirds of the total energy demand in the UK. About $85 \%$ of UK households use gas for heating and about $40 \%$ of electricity generation also comes from natural gas (UK Government, 2019). The continuous large-scale consumption of gas certainly affects natural gas production, where since 2000 the production of this gas has decreased, which makes the UK position shift from exporting natural gas to importing. Since 2018, the UK has imported more than half of its gas supply and expects to import more than $72 \%$ of gas by 2030 (UK Government, 2019). According to the British Geological Survey (BGS), UK has a considerable enough potential for shale gas reserves, such as in the Shale Bowland of northern England, which is estimated to contain around 1,300 trillion cubic feet (Tcf) of gas (UK Government, 2019). In comparison, the UK only consumes about 3 Tcf per year. However, only about $4 \%$ of the gas in Bowland can be extracted (ECIU, 2016). The large potential for shale gas reserves owned by the UK has motivated the British Government to explore energy resources for long-term energy fulfillment. In March 2011, the first exploration of shale gas using the fracking method began at Preese Hall, Lancashire, by an energy exploration company, Cuadrilla Resources.

Fracking is a complex technology, where there is no scientific consensus on the long-term sustainability of the use of the fracking method as a climate change mitigation technology and alternative energy source. The Chartered Institution of Water and Environmental Management states that many of the concerns about fracking in the UK result from the experience of fracking regulation in the United States (White \& Fell, 2015). The use of the fracking method often causes various detrimental impacts on the community's environment, health, and social life, such as:

\section{Water Contamination}

In the shale gas extraction process, there is a risk of groundwater contamination due to errors in the construction or operation of wells. Besides, the use of the fracking method requires large amounts of water to extract shale gas, which can put considerable pressure on the water supply around the drilling area. If the water supply decreases due to the pressure, water availability for daily needs will be difficult to obtain. Moreover, it also causes some habitat loss in the water, changes 
in water temperature, increases in sedimentation, impacts on the livelihoods of farmers who depend on water supply, and so on (Esterhuyse \& Avenant, 2014).

Surface water quality is one aspect that is likely to be affected by the use of the fracking method. Not all impacts on surface water are direct. Many impacts are indirect, such as groundwater contaminated by chemical substances, which then flows through springs to surface water. Another possibility is air pollutants that dissolve in rainwater and end up in surface water (Esterhuyse \& Avenant, 2014). Chemicals that can contaminate surface water include methanol, uranium, naphthalene, carcinogens, mercury, and several other substances that tend to be corrosive.

\section{Damage to Soil}

The extraction of shale gas can also have a major impact on the soil. Soil can function as a pathway for contaminants that can contaminate surface water, groundwater, and also plants. The implementation of fracking activities often causes the rain infiltration rate to decrease and the surface water flow increases, causing more soil erosion. The industry regulator report by the Oil and Gas Authority (OGA) contains various kinds of impacts from fracking activities which caused more than 50 earthquakes and 134 seismic instability events around the drilling location using the fracking method (United Kingdom Government, 2019). Apart from causing seismic instability, another impact of fracking activities is the loss of biodiversity due to decreased ecosystem resilience at mining sites. This will also have a significant adverse effect on ecosystem function, as the sites used for exploration and exploitation will pose a considerable threat to vegetation communities. Construction on the drilling sites will have several impacts that affect native vegetation, such as new plant diseases, slow growth of plants, and death of a number of plants.

\section{Impact on Health}

A study conducted by Colborn, identified that fracking activities in the United States contain about 632 chemicals. More than $75 \%$ of these chemicals can affect health problems such as skin, eyes, respiratory system, digestive system, potentially affecting the brain and nervous system about $40-50 \%$. About $25 \%$ have the potential to cause cancer (Waugh, 2020). An example of what happened was that of a family in Texas who was drilling a shale gas well within a 2-mile radius. The girl in the family develops symptoms including nosebleeds, nausea, rash, fever, and high blood pressure. In the end, the family brought substantial evidences and filed a lawsuit against Aruba Petroleum, which operates most of the wells in the location, to be responsible for the family's health problems (Waugh, 2020). It can also be 
ascertained that the Lancashire region has a higher average rate of people with common mental disorders (CMD) than other regions, such as the incidence of fear, anger, anxiety and sleep disorders (Short \& Szolucha, 2019).

Specifically, the health effects of fracking activities in the UK can also affect women. A study by Concerned Health Professionals of New York found that pregnant women living near active fracking surgery in Pennsylvania had a 40\% increased risk of preterm delivery and $30 \%$ had high-risk pregnancies. Therefore, this can increase the percentage of cases of miscarriage or stillbirth caused by heavy metals in fracking wastewater. There are also fertility and menstrual problems in women potentially caused by exposure to chemicals associated with fracking, including benzene, toluene, and xylene. Reflecting on the United States' experience on the impact caused by fracking activities, it can be a reference for British people to be aware of the people living near the drilling locations of fracking (Hayhurst, 2019).

\section{Public and Government Responses to Fracking Activities in United Kingdom}

The British public's response to fracking activities cannot be said to be one-sided only. Several parties show their support for the implementation of fracking activities instead so that it creates two camps between the pro-fracking and the antifracking.

\section{The Pro - Fracking}

The pro-fracking camp believes that the implementation of fracking activities can provide greater benefits so that it can cover all existing impacts and losses. Generally, pro-fracking parties are more supported by bureaucrats and stakeholders such as coalitions of governments, oil and gas companies, and industrial networks that are involved in implementing fracking activities, which embrace the discourse of opportunity and try to convince others of its benefits (UK Government, 2019). The pro-fracking party believes that fracking activities will be in line with the opening of more jobs. Besides, fracking activities can also open up space for foreign investors to invest in the project. Meanwhile, in terms of security, the UK can build its energy independence by discovering unconventional gas reserves. In terms of assurance, the pro-fracking people are optimistic that current technology (fracking) can minimize the potential for environmental damage, as innovation and research can increase the percentage level of security. For them, the anti-fracking response is only a concern that cannot be proven empirically (Bomberg, 2015). Prime Minister David Cameron also stated that exploration opportunities for shale gas energy would increase new jobs by as many as 74,000 types of jobs (Perraudin \& Pidd, 2014). This will bring the UK to a state of energy 
independence and reduce dependence on other countries in terms of natural gas imports.

\section{Anti-Fracking Parties}

In addition to those who agree to carry out fracking activities, other parties oppose these activities. Anti-fracking parties are mostly dominated by local NGOs, environmental activists, and local communities who directly feel the impact of implementing fracking activities. The first major protests against fracking in England and Wales took place in the summer of 2013 in Balcombe, Sussex, where a coalition of local groups and environmental activists set up a protest camp on an exploration drilling site run by energy company Cuadrilla (CPRE, 2018). Since 2013, there have been protests at sites across the UK in Cheshire, Derbyshire, East Yorkshire, Greater Manchester, Lancashire, North Yorkshire, Nottinghamshire, Shropshire, Surrey and Sussex (CPRE, 2018). One NGO that expressed its public disapproval of fracking in England is Friends of the Earth. Friends of the Earth utilizes information or testimonials quickly and credibly on their website, which contains various kinds of information or accurate data related to the implementation of fracking, which tends to be harmful to the environment. The impact arising from the fracking activities is a threat to the environment, democracy and accountability. It highlights the lack of transparency and feedback from the public. The disclosed facts then made other people who may not care about the environment became worried about the problems of democracy and low accountability from the British Government.

The pro-fracking parties claim that fracking activities can reduce the current unemployment rate in the UK. However, these claims are more based on optimistic assumptions about how much gas can be produced in reality. One fracking company Cuadrilla claims that the production of shale gas in Lancashire will create as many as 1,700 jobs, but this is only for one year, which then drops to under 200 in the following three years (Friends of the Earth, 2019). In addition, the implementation of fracking activities can also endanger existing fields of work around drilling sites that rely on clean air, land, water, or a calm environment, which can suffer losses from these changes such as agriculture, tourism, organic farming, hunting, fishing, and outdoor recreation.

However, there is a pattern of limited advocacy and activism between local people against British Government in the anti-fracking movement due to the British focus that has not put forward the climate change agenda. It hinders the flow of advocacy and public activism against the British Government. More than 200 arrests of demonstrators included the detention of children, pregnant women, elderly people, and the arrest of women using violent means (Jackson \& Monk, 2014). Also, the UK 
Government does not have a written environmental constitution or environmental provisions explicitly protecting individuals' rights affected by fracking activities. This lack of explicit recognition of environmental rights arguably makes it easier for the British Government to promote a pro-fracking agenda in the UK that is aligned with a political agenda rather than broader social and environmental standards and protection. There is a response from the British Government that cannot fulfil the interests of the community, making the international community or NGOs outside the British territorial boundaries begin to voice their disapproval of the implementation of fracking activities.

\section{The Strategies of Transnational Advocacy Network in Supporting the Anti-Fracking Movement in the United Kingdom}

TAN involves non-state actors such as NGOs, International Organizations, or even individuals. Of the various actors in an international advocacy network, NGOs are one of the important actors in pushing for a change in policy. In the case of fracking in the UK, persuasive actions were shown by several NGOs, namely Friends of the Earth, Global Frackdown, World Wildlife Fund United Kingdom (WWF - UK), Greenpeace, Talk Fracking, Frack Free United, and several other NGOs. One of the most vocal NGOs in opposing fracking activities is Friends of the Earth. It is an international network engaged in the environmental sector, which has members of as many as 74 countries, 5000 local activist groups, and more than 2 million members or supporters worldwide. When relations between the state and domestic actors are cut, local NGOs will seek alliances from international networks to exert pressure on the Government, in order to fulfill individual or group rights that could not be obtained previously (Keck \& Sikkink, 1999).

The transnational advocacy network is a structure produced through the continuous practice of the agents to shape the interests and identities of the agents who contribute to it. Actors such as NGOs, international organizations, and individuals are agents that form a structure through a discourse, norms, ideas, and a series of existing regulations. The action against the implementation of fracking activities in the UK was attended by more than 400 groups and activists, almost half of which have various information exchange platforms such as websites, Facebook, Instagram and Twitter which can be disseminated to a wider domain (Short \& Szolucha, 2017). This then shows that the online platforms used by environmental activists or NGOs can accommodate networks for information exchange between non-state actors.

In 2013, Friends of the Earth, Greenpeace UK, and World Wildlife Fund (WWF) also conducted direct advocacy to the House of Lords or the British Upper House 
regarding their views on the ongoing issue of fracking in the UK. Gareth RedmondKing as Head of Energy and Climate at WWF - UK stated that several industry players were trying hard to present shale gas as a solution to all domestic energy problems (WWF, 2017). However, the reality is that the risks associated with fracking tend to be unpredictable, and greenhouse gas emissions may worsen than coal exploration. Therefore, WWF UK's decision to support banning fracking activities in the UK is the right decision.

In the TAN scheme, there are several strategies that an NGO or other actors can take in playing its role, namely through Information Politics, Symbolic Politics, Leverage Politics, and Accountability Politics as previously described (Keck \& Sikkink, 1999). Friends of the Earth, has implemented several strategies in TAN to achieve its goals as follows:

\section{Information Politics}

Friends of the Earth's movement in using information or testimonials quickly and credibly can be seen freely by the broader community in various ways. Friends of the Earth use many information exchange techniques, including through several social media platforms such as Instagram with the username "friends_earth", Twitter with the username "@friends_earth" and the official website, www.foei.org. Some of these information exchange platforms contain various kinds of information or accurate data related to fracking's harmful effects to the environment. The website also provides petition platforms for anyone who wants to participate in the UK's opposition to fracking. Various information on this platform offers facts and provides testimony and stories from people directly affected by certain issues.

On the official website of Friends of the Earth UK, there is Barbara Richardson's testimony as an example of a community living near the fracking location (Friends of the Earth, 2015). He said that some people do not understand how dangerous the effects of fracking activities are and feel the impact. One of the testimonies outlined in the information dissemination platform was then framed in a simple way to persuade and encourage the international community to take action and create joint solutions. In the end, the widespread dissemination of information through various existing platforms can have significant impacts on changing state behavior in formulating policies to prohibit fracking activities in the UK. 
2. Symbolic Politics

Friends of the Earth's ability to compose stories, actions, or other symbols to support the information conveyed in increasing public awareness is contained in its movement on social media by creating a hashtag, namely \#ProtectOurFuture, \#FrackFree, \#NoFracking, and \#BanFracking (Friends of The Earth, 2017). The spread of symbols through hashtags or hashtags in various kinds of social media can support the growth of the network where symbolic interpretation is part of the persuasion process to create public awareness and expand constituencies. Ultimately this connected network will accelerate the spread of discourse across national borders and lead to policy or political change in a country. TAN can be a proof that there is public dissatisfaction with the regime in power, so that it requires resolving solutions from other aspects. In this case, social media's role as a means of disseminating discourse has become significant, thus motivating the international community to take the same steps by conveying certain symbols.

The Friends of the Earth movement globally can be seen from how they mobilize issues through protests against fracking activities attended by more than twenty countries on five continents, incorporated in the so-called Global Frackdown. The Global Frackdown Action was initiated by several local and international NGOs such as Food \& Water Watch, Environment America, 350.org, Friends of the Earth, and several other humanitarian organizations. Global Frackdown is part of international action in the energy sector, which lasted for almost a month, in more than twenty countries such as the United Kingdom, the United States, South Africa, Scotland, France and other countries. Global Frackdown has succeeded in uniting the activist movement and spearheading more than 150 events and demonstrations on five continents calling for a ban on fracking activities (Friends of the Earth Europe, 2013).

\section{Leverage Politics}

Friends of the Earth also uses influential actors to suppress other actors. This can be seen in the involvement of a number of community leaders who also support anti-fracking actions on social media. Several community leaders such as Mark Ruffalo and Mark Rylance also expressed their official rejection of the implementation of fracking and signed a petition to paralyze the implementation of fracking (Peters, 2019). In his interview session with Friends of The Earth, Mark Ruffalo conveyed a message to Prime Minister David Cameron that he had broken his promise to listen to the British public's aspirations in rejecting fracking activities in the UK (Friends of the Earth, 2016). In addition, Mark Rylance as an actor and director in several Hollywood films, officially supports the action against fracking activities together with Friends of The Earth. In his interview session with Friends 
of The Earth, Mark Rylance expressed his disapproval of the implementation of fracking activities located around the Sherwood Forest (Friends of the Earth, 2018). Sherwood Forest is one of the oldest forests in England and is famous for its historical association with the Robin Hood legend.

Mark Ruffalo and Mark Rylance are public figures who have followers in almost all parts of the world. On his Instagram account, Mark Ruffalo has followers of up to 19 million who come from all parts of the world. The community supports Mark Ruffalo's participation in supporting this anti-fracking campaign because he represents the public's voice in rejecting fracking activities in the UK (Vaughan, 2016). The implication is the increasing public awareness due to information obtained from community leaders who have a strong influence. It then becomes a strategic step to influence policy changes to prohibit fracking activities in the UK.

Some of the roles of international advocacy networks were also played by other opposing groups. A group of environmental activists, academics, along with several public figures such as Amber Heard and Vivienne Westwood, have also urged the United Nations to ban fracking activities in the UK. Hollywood actress Amber Heard and the opposing group made a statement of her disapproval of fracking activities in the UK in a letter to eliminate All Forms of Discrimination Against Women in the Geneva meeting. In the letter, there is a statement that the British Government's actions are not enough to protect women who live around the drilling location. In this case, celebrities have the capacity to attract public attention and mobilize public involvement in social activities that involve them. In this case, it will be difficult for the Government to rebuff a public figure's statement, which gets more public sympathy (Huliaras \& Tzifakis, 2010).

\section{Accountability Politics}

This strategy is an effort to evaluate the results of advocacy that has been achieved, to test the Government's accountability through the implementation of policies on a particular issue with an agreed commitment. The British Government announced a moratorium or temporary ban on all kinds of fracking activities in the UK on 2 November 2019. The parties who oppose the implementation of fracking activities, welcome the British Government's decision. The anti-fracking movement in the UK, which involves more than 400 groups, has yielded a result. However, looking at the results of the Government's decision which was limited to proclaiming a temporary ban on the implementation of fracking activities, made activists do not immediately stop observing the case and accept the raw decision. Through the Accountability Politics strategy, activists, NGOs, and other anti-fracking supporters have been still monitoring the results of the decisions to make sure that they run according to the British Government's commitments. The public also waits for the British 
Government's decision to change the moratorium or temporary ban into a permanent ban on fracking activities. Therefore, until now, efforts to evaluate the results of advocacy for fracking activities in the UK are still being carried out by activists or other NGOs.

\section{Results of the Efforts of Transnational Advocacy Networks in Anti-Fracking Movement in the United Kingdom}

The role of TAN is proven to be able to help them achieve their desired goals. According to research conducted by the British Government, public opposition to the implementation of fracking activities has almost doubled from $21 \%$ in 2013 to $40 \%$ in 2019, and support for implementing fracking activities has fallen from $27 \%$ to $12 \%$ (Loughran, 2019). The significant increase in opposition to the implementation of fracking activities from the British public ultimately became a major consideration for the Government to stop the implementation of these fracking activities. This consideration was shown by Boris Johnson as the British Prime Minister in October 2019, before the moratorium on fracking activities in the UK was officially implemented (Loughran, 2019). Boris Johnson stated that the British Government's consideration of banning fracking activities was based on public opinion that was increasingly opposed to the activity.

Apart from getting strong opposition from within the country, the international advocacy network's efforts have created external pressure, which prompted the British Government to temporarily ban all kinds of fracking activities in the UK. The European Union, for example, has shown a commitment to anti-fracking through the adoption of Recommendations (2014/70 / EU) in 2014, which were appointed in the Green Council Copenhagen Spring 2012 by the European Greens Party (European Parliamentary Research Service, 2014). In this regard, the European Union shows its full commitment and puts pressure on member countries to minimize fracking's action and its impacts. Responding to the issue of relations between the UK and the European Union, this will certainly relate to the Brexit case which will indirectly have an impact on the implementation of fracking activities in the UK. The laws governing the implementation of fracking activities come from fifteen different European Laws. This includes the EU-wide treaties relating to water contamination, air pollution, chemicals, climate change, biodiversity, environmental responsibility. regulate who is to blame for the negative impact, and several other regulations (Friends of the Earth, 2018). If these rules are not properly transferred into English law, the inadequate regulations against the conduct of fracking activities are likely to be weak.

A committee at the United Nations has also recommended that the British Government consider a comprehensive ban on Britain's fracking activity. This was 
further strengthened by the many groups of environmental activists and the international community voicing their disapproval of the implementation of fracking in the UK at the UN Convention on the Elimination of Discrimination Against Women (CEDAW) meeting (Hayhurst, 2019). In 2018, CEDAW began to raise the issue of UK fracking, then asked the UK government to provide information on steps being taken to reduce and address its health and environmental impacts. In the end a warning regarding the prohibition of the implementation of fracking activities was issued by the Committee on the Elimination of Discrimination against Women (CEDAW) through a recommendation (CEDAW / C / GBR / CO / 8) to completely ban the practice of fracking on March 14, 2019 (Hayhurst, 2019). According to the CEDAW representative, the use of the fracking method needs to be considered more carefully because of the impacts on the environment and health of the surrounding community. As noted by CEDAW, the implementation of fracking activities often has a disproportionate impact on women and girls, because they can be directly exposed to various kinds of hazardous chemicals, environmental pollution, and can cause feelings of anxiety or anxiety in the mother because they are unable to protect the family.

In August 2019, there was a 2.9 magnitude earthquake which was triggered by fracking activity where this seismic activity had exceeded the safety level agreed upon by the Government. The British Government stated that it was no longer possible to override the consequences felt by the people around the fracking locations. Based on the consideration of increasing public opposition to the practice of fracking and its irreversible impact, on 2 November 2019 the British Government finally declared an official decision regarding a comprehensive ban or moratorium on the implementation of fracking in the UK. The British Government stated that the decision to ban fracking activities was based on the community movement's strength who opposed the fracking activity method at every opportunity. The spread of the fracking issue carried out by this advocacy network is one of the factors in the change in British government policy regarding fracking.

The use of the concept of the Transnational Advocacy Network proves that there are networks that are connected between individuals and groups that penetrate the territorial boundaries of a country. This is evidenced by the existence of various activist movements around the world that raise similar issues, namely AntiFracking. Friends of the Earth is one of the NGOs that has a strong network in connecting information to other NGOs or groups that are outside the anti-fracking activism movement. The Friends of the Earth movement globally can be seen from how they mobilize issues through protests against fracking activities, which are attended by more than twenty countries on five continents, which is contained in 
an action called Global Frackdown. Global Frackdown has succeeded in uniting the activist movement and spearheading more than 150 events and demonstrations on five continents using a strategy based on the concept of the Transnational Advocacy Network (Friends of the Earth Europe, 2013). It can be concluded that the Friends of the Earth movement triggered a transnational activism movement, thus influencing Fracking's policy changes in the UK.

Following the UK government's ban on fracking, Friends of the Earth and its networking transnational NGOs also recommend some actions to keep in mind, including ensuring that the temporary ban becomes permanent, so it doesn't happen again in the future. Moreover, Friends of the Earth also suggests the Government to end all unconventional energy explorations that use extreme methods and fully support anti-fracking measures in the UK and in many other regions.

\section{CONCLUSIONS}

The implementation of fracking activities in the UK has a number of dangerous impacts in various aspects such as the environment, health and others. Those adverse impacts have led to the emergence of a movement against fracking activities in several areas such as Lancashire, Blackpool, Manchester, and in several other areas. However, there is a pattern of limited advocacy and activism between local communities and British regulations. This is evidenced by the arrests of more than 200 demonstrators, including the detention of children, pregnant women, the elderly, sometimes using violent means (Jackson \& Monk, 2014). This pressuring situation then made Friends of the Earth mobilizing these issues to the international realm by promoting ideas or norms to form a transnational network, aiming to influence British government policy. This network is called the Transnational Advocacy Network. Activists carry out various kinds of activism through a series of strategies in the Transnational Advocacy Network, such as Information Politics, Symbolic Politics, Leverage Politics, and Accountability Politics. The strategies are in line with the Constructivist approach, which assumes that interaction patterns are formed by several elements such as norms, identity, values, language and intentions that can change a point of view. Those who oppose fracking activities, such as activists or NGOs, also convey these norms, identities, values, language and intentions in their advocacy efforts.

The demonstrators' advocacy efforts began to get strong support from anti-fracking communities, either in domestic and international realms. TAN has triggered external pressure to the Government, which prompted the British Government to enact stricter regulation to all kinds of fracking activities in the UK. Based on the consideration of increasing public opposition to the practice of fracking on 
November 2, 2019, the British Government finally declared an official decision regarding a comprehensive ban or moratorium on the implementation of fracking in the UK. Based on the research that the authors has conducted, it can be concluded that the role of TAN in supporting the anti-fracking movement in Britain has succeeded to a certain degree. The set of strategies in play by opponents of fracking activities has proven to make a significant contribution in mobilizing issues related to the UK's anti-fracking movement more broadly. An international advocacy network using several advocacy strategies in it is beneficial for the community to express their opinions more freely. 


\section{REFERENCES}

Bakry, Umar Suryadi. (2016). "Metode Penelitian Hubungan Internasional". Yogyakarta : Pustaka Pelajar.

Bomberg, E. (2017). Shale We Drill? Discourse Dynamics in UK Fracking Debates. Journal of Environmental Policy and Planning, 19(1), 72-88.

British Geological Society. (2018). "Risks from fracking to be studied by top UK research team". Accessed on 14 September 2020, at: https://www.bgs.ac.uk/news/risks-from-fracking-to-be-studied-by-topuk-research-team/

CPRE. (2018). "What is fracking?”. CRPE. Accessed on 14 September 2020, at: https://www.cpre.org.uk/news/whatisfracking/?gclid=CjwKCAjwgdX4BRB_EiwAg8O8HQIootZ4QiCz1ChIpol k7610MmyHO7rhvPXAgant_sAPB4_ry9FPRoC2ZQQAvD_BweE

Creswell, John W. (2013). "Research Design : Qualitative, Quantitative, and Mixed Methods Approaches”. California : SAGE Publications.

ECIU. (2016). "Fracking in the UK. Energy \& Climate Intelligence Unit". Accessed on 14 September 2020, at: https://eciu.net/analysis/briefings/ukenergypolicies-and-prices/frackingin-the-uk

Esterhuyse \& Avenant. (2014). "Development of an Interactive Vulnerability Map and Monitoring Framework to Assess the Potential Environmental Impact of Unconventional Oil and Gas Extraction by Means of Hydraulic Fracturing". Accessed on 3 Desember 2019, at: http://www.wrc.org.za/wpcontent/uploads/mdocs/2149-1-14.pdf

European Parliamentary Research Service. (2014). "European Council Conclusions: A Rolling Check-List of Commitments to Date". Accessed on 30 November 2019, https://www.europarl.europa.eu/EPRS/European_Council_Conclusions26JUNE2014.pdf

Friends of the Earth Europe. (2013). "Global Frackdown Day". Accessed on 30 November 2019, at: https://www.foeeurope.org/global-frackdown-day221013 
Friends of the Earth. (2015). "'I am opposed to fracking because it will devastate our community'". Accessed on 30 November 2019, at: https://friendsoftheearth.uk/climate-change/i-am-opposed-frackingbecause-it-will-devastate-our-community

Friends of the Earth. (2016). Hollywood star sends heartfelt fracking plea to PM. Accessed on 30 November 2019, at: https://friendsoftheearth.uk/climate/hollywood-star-sends-heartfeltfracking-plea-pm

Friends of The Earth. (2017). Beating Climate Change and Fracking. Friends of The Earth. Accessed on 14 September 2020, at: https://cdn.friendsoftheearth.uk/sites/default/files/downloads/Web\%20 Climate\%20DOA\%2ofracking\%2oflyer.pdf

Friends of the Earth. (2018). Mark Rylance wants you to save Sherwood Forest. Accessed on 30 November 2019, at: https://friendsoftheearth.uk/climatechange/mark-rylance-sherwood-forest-fracking

Friends of the Earth. (2019). Stop Fracking Action Pack. Accessed on 30 November 2019, at: https://cdn.friendsoftheearth.uk/sites/default/files/downloads/stopfracking-action-pack-D7.pdf

Gilmore, J. (2019). Protesters' experiences of policing at anti-fracking protests in England, 2016-2019 : a national study. Centre for the Study of Crime, Criminalisation and Social Exclusion, Liverpool John Moores University.

Hayhurst, R. (March 13, 2019). UN committee urges the UK government to ban fracking". DRILL OR DROP?. Accessed on 14 September 2020, at: https://drillordrop.com/2019/03/13/un-committee-urges-ukgovernment-to-ban-fracking/

Hayhurst, R. (Nov 2, 2019). Government orders immediate moratorium on fracking in England because of tremor risk. Accessed on 30 November 2019, at: https://drillordrop.com/2019/11/02/immediate-moratorium-onfracking-in-england-because-of-tremor-risk

Huliaras, A. \& Tzifakis, N. (2010). Celebrity Activism in International Relations: In Search of a Framework for Analysis. Global Society, 24(2), 255-274. doi:10.1080/13600821003626567 
Jackson, W.H. \& Monk, H. (2014). Police violence at anti-fracking protests: pacifying disruptive subjects. Accessed on 3 Desember 2019, at: http://researchonline.ljmu.ac.uk/id/eprint/626/1/CJM\%20article\%20B M.pdf

Keck, M.E. and Sikkink, K. (1999). Transnational Advocacy Networks inInternational and Regional Politics. International Social Science Journal, 51, 89-101.

Lamont, C. (2015). Research Methods in International Relations. SAGEPublications Ltd

Loughran, J. (2019). Boris Johnson has hinted that a fracking ban in the UK could be imminent, with research showing that the British public are increasingly opposed to the practice. Accessed on 30 November 2019, at: https://eandt.theiet.org/content/articles/2019/10/fracking-underpressure-as-johnson-considers-uk-ban

Perraudin, F. \& Pidd H. (2018). Anger and blockades as fracking starts in UK for first time since 2011. Accessed on 14 September 2020, at: https://www.theguardian.com/environment/2018/oct/15/frackingprotesters-blockade-cuadrilla-site-where-uk-work-due-to-restart.

Peters, J. (2019). The Fracking Ban : What does it means?. Accessed on 14 September 2020, at: https://friendsoftheearth.uk/climatechange/fracking-ban-what-does-it-mean

Short, D. \& Szolucha, A. (2017). Fracking Lancashire: The planning process, social harm and collectivetrauma. Accessed on 30 November 2019, at: https://doi.org/10.1016/j.geoforum.2017.03.001

United Kingdom Government. (2019). Government ends support for fracking. Accessed on 30 November 2019, at: https://www.gov.uk/government/news/government-ends-support-forfracking

United Kingdom Government. (March 12, 2019). Guidance on fracking: developing shale gas in the UK. Accessed on 3 Desember 2019, at: https://www.gov.uk/government/publications/about-shale-gas-andhydraulic-fracturing-fracking/developing-shale-oil-and-gas-in-theuk\#contents 
Vaughan, A. (2016). Mark Ruffalo tells Cameron his UK fracking push is an 'enormous mistake. Accessed on 30 November 2019, at: https://www.theguardian.com/environment/2016/feb/o8/mark-ruffalotells-cameron-his-uk-fracking-push-is-an-enormous-mistake

Waugh, R. (2020). 'All out for shale' : The mental health impacts of the Government's fracking policy: evidence from Lancashire, England. Accessed on 30 November 2019, at: https://lup.lub.lu.se/luur/download?func $=$ downloadFile\&recordOId $=903$ 1360\&fileOId $=9031362$

White, E. \& Fell, M. (2015). Shale gas and fracking. Accessed on 3 Desember 2019, at:http://researchbriefings.files.parliament.uk/documents/CDP-20160018/CBPo6073.pdf

WWF. (2017). WWF Reacts to the Defeat of the Lanchashire Anti-Fracking Campaigners at the High Court. Accessed on 30 November 2019, at: https://www.wwf.org.uk/updates/wwf-reacts-defeat-lancashire-antifracking-campaigners-high-court 